\title{
Depreciation as Applied to Oil Properties
}

\author{
BY PHILIP W. HENRY, NEW YORK, N. Y.
}

(Now York Mooting, Fobruary, 1915)

THERE is a difference of opinion among engineers on the subject of depreciation in general, and still more on its application to any given case The committee which was appointed by the American Society of Civil Engineers to make a report on Valuation of Public Utilities, states "There is no subject connected with valuation about which there are more diverse views than those relating to depreciation;" and in the discussion which took place upon the presentation of the preliminary report of this committee in January, 1914, that part of the report dealing with depreciation called forth more discussion than any other. From this discussion it was evident that the word "depreciation" was not always used in the same sense, so it is quite important that some definition be adopted. As this paper relates to the proper method of treating depreciation by corporations or individuals operating oil properties, both of which must make a return of annual net income to the government in connection with the income tax, it will be in order to adopt the definition of the Internal Revenue Bureau. Under date of Mar. 29, 1910, the Commissioner of Internal Revenue of the Treasury Department stated "Deduction on account of depreciation of property must be based on lifetime of property, its cost, value and use." Again, on Form 1035, "Return of Annual Net Income" for miscellaneous corporations (Section 2, Act of Congress approved Oct. 3, 1913), a deduction from gross income is allowed for "Total amount of depreciation for the year." This item is defined more particularly as follows:

"The amount claimed under Item No. 5 (b) for depreciation should be such an amount as measures the loss which the corporation actually sustains during the year in the value of buildings, machinery, and such other property as is subject to depreciation on account of wear and tear, exhaustion, or obsolescence. The amount taken credit for on this account in order to be allowable should be so entered on the books as to constitute a liability against the assets of the corporation. The amount claimed under this item should not cover losses in the value of stocks and bonds. Decrease in the book value of securities owned, so far as such decrease represents a decline in the actual value of such securities, should be deducted under item $5(a)$ of the return.

"Where depreciation of physical property is made good by renewals, replacements, 
repairs, etc., and the expense of such renewals, replacements, repairs, etc., is charged to the general expense account, no deduction for depreciation can be made in the return of annual net income. Where a depreciation reserve is set up, all renewals and replacements must be charged to such reserve and the addition to this reserve each year must be a fair measure of the loss which the corporation sustains by reason of the depreciation of its property."

Here the Internal Revenue Bureau recognizes that depreciation includes wear and tear, exhaustion, and obsolescence, and that in arriving at the amount to be charged off each year there must be taken into account the lifetime of the property, its cost, value, and use. The Bureau also indicates the difference between depreciation and ordinary wear and tear -more or less uniform in amount each year-which is generally carried as a regular operating account under the designation of "repairs and renewals" or some similar title. The Bureau also refers to the setting up of a "depreciation reserve," which is undoubtedly the best way to treat depreciation on the books, where it is carried as a credit account, although on the balance sheet it may be shown either on the credit side as a liability or on the debit side as a deduction from one or more of the property accounts. This account should be credited annually (or preferably monthly) with an amount sufficient to provide a fund to take care of the cost of deferred or final renewals, and in the case of an oil property, to provide a fund to balance the depletion of oil lands. As depreciation reserve is both a debit and a credit account, against it should be charged the cost of deferred and final renewals when made. By so doing the annual net income is not affected by large expenditures made in any one year for new plant to replace that which has been discarded on account of deterioration, inadequacy, or obsolescence. Depreciation reserve should also be charged. with the cost of such new oil lands as are necessary to maintain the original value of oil lands. Theoretically, the amount standing in depreciation reserve at any given time plus the value at that time should equal the original value; but seldom does this condition obtain, as it is exceedingly difficult to determine the proper amount to set aside each year in depreciation reserve. Strictly speaking, the only way to arrive at this amount is to make a careful valuation each year, and debit or credit depreciation reserve accordingly. Manifestly such yearly valuation is impracticable, and it is more convenient to assume a lifetime for each item making up the property, and it is this method which is recommended by the Internal Revenue Bureau. It is therefore evident that the annual allowance for depreciation cannot be determined with mathematical accuracy, as both the lifetime and the condition of any property or of its component parts are only estimates, on which no two engineers will agree in detail. It would therefore seem that, particularly as applied to oil properties, any discussion as to the relative merits of the various methods of setting aside an annual amount for depreciation would introduce a voL. LI. -36 
refinement not warranted by conditions. Mention, however, will be made of the three principal methods. By the sinking-fund method a certain equal percentage is set aside each year, which, being compounded annually at a given rate of interest, will at the end of the assumed lifetime amount to the original value. By the equal-annual-payment method certain increasing percentages are set aside each year, which, without interest, will at the end of the assumed lifetime amount to the original value. By the straight-line method a certain equal percentage is set aside each year, which, without interest, will at the end of the assumed lifetime amount to the original value. For oil properties, with an inevitably decreasing production (after maximum is reached), it would seem that some method should be adopted by which decreasing percentages should be set aside each year for depreciation. Such a method would more nearly equalize the depreciation charge per barrel of production. On the other hand, it is a question whether, on account of the higher selling price which generally obtains as an oil field is depleted, the later years cannot stand a higher depreciation charge per barrel. In view of these uncertainties it would seem that the straight-line method is simplest and best, for, owing to the extreme difficulty in arriving at the lifetime of the various items making up the property, the greater exactness called for by the other methods is unnecessary. No matter what method is adopted and no matter how conscientiously and intelligently applied, in all probability the experience of a few years will show that the amount in depreciation reserve is too large or too small, and that the annual rate of depreciation should be changed accordingly. For this reason it is advisable to adopt at proper intervals what has been termed the actual-inspection method, by making a physical valuation of those parts of the property susceptible to depreciation, in order to determine whether or not the amount in depreciation reserve is equal to the original value less present value, as it should be-leaving out of consideration the effect which appreciation and other elements connected with valuation may have on the subject, and assuming that original cost and original value are equivalent terms.

While the proper treatment of depreciation is required by the government for purposes of taxation, it is of still greater importance to the stockholder, for only then does he know that his investment is being kept up to its original value, and that the dividends paid, whether 10,50 , or 100 per cent., are really earned. Whether depreciation reserve is invested in outside securities, as may be advisable in the declining days of an oil property, or whether invested in the property itself for betterments and additions, is immaterial. If properly set aside, the stockholder knows that out of earnings each year has been provided a fund, not applicable to dividends, which maintains his investment at a constant value, and which, when the oil is exhausted, will be sufficient, together with the value of the remaining property, to pay him back his principal. This of courserepre- 
sents an ideal condition, seldom realized in practice; for while it is very easy to enunciate principles, it is most difficult to apply them to the particular case in hand. Such application, however, will now be attempted.

First of all, the lifetime of every item entering into the property should be established, and a depreciation reserve set aside annually for each item based upon such lifetime, or an average lifetime established for the entire property. An oil property, the lifetime of which as a whole, or in part, is so uncertain, may be considered as being made up of three classes, viz.: oil lands, field equipment, and wells. In field equipment should be included tanks, reservoirs, pipe lines, loading racks, water system, power plants, structures of various kinds, and miscellaneous items belonging to the field as a whole rather than to the individual well. In wells should be included the well itself and those appurtenances, the lifetime of which depends more upon the individual well than upon the field. This simplifies the matter in that only the average lifetimes of the oil lands, the field equipment, and the individual well need be established, thus reducing book entries to a minimum.

It is manifestly beyond the province of this paper to select any particular oil property for the purpose of illustrating the general principles of depreciation, and even were such property thus selected, the application of those principles to that particular case would have no more value when applied to another property, than if the field as a whole or even a State as a whole, such as California, were selected for purposes of illustration. It is obvious that a rate of depreciation established for the property containing the Lakeview gusher, for example, would be of little value when applied to another property in the same field, or even to an adjoining property. For this reason the State of California as a whole has been selected for purposes of illustration, and it is believed that the end in view will be better served than if some specific property were taken. In establishing the lifetime of the oil fields of California as a whole or in part, the best recourse is to the United States Geological Survey, which for years has made a careful study of the various oil fields of the United States and publishes a report every year upon the subject. For California the Survey has estimated that the original contents of the probable oil lands were somewhere between $5,000,000,000$ and $8,500,000,000$ barrels, or from one-third to one-half of the entire probable production of the United States. There have been produced in California as a total to date some $750,000,000$ barrels, leaving still in the ground from $4,250,000,000$ to $7,750,000,000$ barrels. At the present rate of production, $100,000,000$ barrels yearly, it will take from $42 \frac{1}{2}$ to $77 \frac{1}{2}$ years to exhaust the oil, with an average of 60 years. It must be remembered, however, that within the past 10 years the annual production of the State has trebled and within the last five has doubled, the production in 1904 having been $32,743,273$ barrels and in $1909,54,433,010$ barrels. 
On account of this constant annual increase in production, as well as the danger from water intrusion, which seriously threatens some fields of the State, it would seem prudent to adopt a lifetime of not more than 25 years for the field; and assuming that the oil lands owned by the hypothetical company under consideration are up to the average, a depreciation rate of 4 per cent. per annum is indicated upon their cost, in this case considering cost and value as equivalent terms. This annual rate, being predicated upon total extinction of value in 25 years, will be modified in accordance with the value of the land after the oil is extracted. For example, should the land after the oil is extracted be worth 25 per cent. of its original value, the yearly depreciation rate will be 3 , instead of 4 per cent. For purposes of illustration, however, the land, upon exhaustion of the oil, will be considered as of novalue, which is not far from actual conditions in some parts of California. In order to apply the principle, some cost (value) of oil lands must be assumed, and for purposes of illustration a cost of $\$ 500$ and $\$ 1,000$ respectively per barrel of daily production will be used. On a production of 1,000 barrels per day, the cost will be $\$ 500,000$ and $\$ 1,000,000$ respectively, with yearly depreciation charges of $\$ 20,000$ and $\$ 40,000$ respectively, which on a yearly production of 365,000 barrels amounts to $\$ 0.055$ and $\$ 0.110$ respectively per barrel. As depreciation charge on oil lands takes the place of royalty paid by companies operating under lease, the results obtained are not unreasonable.

In order to establish the lifetime of field equipment, that of each component part must be estimated and a general average established. Some of the equipment may last the lifetime of the field. Other parts may have to be renewed every five years, so that here again each property must be studied by itself. Assuming an average lifetime of about 15 years, which seems not unreasonable, an annual depreciation rate of 7 per cent. is indicated. In applying this rate to a company of which I have knowledge, with a field equipment costing $\$ 150,000$ per 1,000 barrels of production daily, the annual depreciation charge will be $\$ 10,500$, or $\$ 0.029$ per barrel. In applying to another company of which I have knowledge, with a field equipment costing $\$ 270,000$ per 1,000 barrels of production daily, the annual depreciation charge will be $\$ 18,900$, or $\$ 0.052$ per barrel.

In regard to the lifetime of an individual well, that again is a local question and must be determined in accordance with facts to be ascertained in each particular field. There are wells in the Kern River district which have been in operation for 15 years and are still producing a fair percentage of their original production, but this is an exceptional field for persistence. In this determination may also be considered the cost of drilling additional wells in order to maintain production at a constant figure. This is frequently carried as a regular operating expense, similar to repairs and renewals, but as depreciation, as herein defined, is a function of capital account rather than of annual production, and as such expense may vary greatly from year to year, it is a question whether drilling 
to maintain production should not be charged into capital account, and depreciated along with the other wells. Such a treatment naturally increases the annual percentage of depreciation, but as this rate is, after all, a matter of estimate and subject to change as new conditions develop, it seems preferable to treat drilling to maintain production as a charge against capital rather than as an ordinary operating expense. Giving due consideration to this element in the problem, 10 years will be assumed as the average lifetime of a well and its appurtenances, taking also into account dry holes, having no lifetime, on the one hand, and those wells which may produce for 20 years or more on the other. Applying this annual depreciation charge of 10 per cent. to one company of which I have knowledge, with an investment of $\$ 190,000$ in cost of drilling wells per 1,000 barrels of production daily, and to another with $\$ 260,000$ so invested, thère will be a yearly depreciation charge of $\$ 19,000$ and $\$ 26,000$ respectively, amounting to $\$ 0.052$ and $\$ 0.071$ respectively per barrel.

Summing up these depreciation charges we arrive at the following results per barrel of production:

Per Barrel

Depreciation on oil lands (royalty) .............. $\$ 0.055$ to $\$ 0.110$

Depreciation on field equipment................ 0.029 to 0.052

Depreciation on wells and appurtenances.......... 0.052 to 0.071

Total depreciation.

$\$ 0.136$ to $\$ 0.233$

These figures must not be regarded either as the minimum or the maximum which may obtain in any given operation, and particularly is this true of oil fields outside of California, and where the persistence of the wells may be greatly different. These figures, however, serve to call attention to the important bearing which a proper charge for depreciation has upon the cost of producing oil in a State where, during the past few years, prices at the well have ranged from 30c. to 85c. per barrel, depending upon the gravity of the oil and the location of the field. It must also be remembered that, in addition to this charge for depreciation, there will be an item for renewals and repairs, charged directly into the cost of operating, which may range from 3c. to 5c. per barrel. It is therefore evident that the actual cost of producing oil in California, no allowance being made for interest on the investment, must in many cases approximate the selling price, as shown in the following statement, based upon experience:

Per Barrel

Pumping............................ \$0.04 to $\$ 0.05$

Miscellaneous field expense................. 0.04 to 0.06

Repairs and renewals.................. 0.04 to 0.05

General expense........................ 0.02 to 0.04

Total direct cost..................

Depreciation as above.................... 0.14 to 0.23

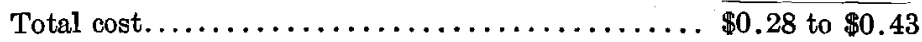


That a proper depreciation charge may be equal to, or greater than, the direct cost per barrel will doubtless surprise many investors in oil properties who consider only immediate expense and immediate profit without regard to the safety of the principal invested.

To engineers, however, who have had the responsibility of operating oil properties, these figures will not be surprising; for in his interesting and valuable paper on Present Conditions in the California Oil Fields, presented to the Institute at its San Francisco meeting in October, 1911, M. L. Requa states: ${ }^{1}$

"It is exceedingly to be regretted that the oil-producers of California, as a whole, do not apparently realize the real cost of production. . . . From territory of, say, 2,500 ft. depth, total costs will approximate from 30 to 35 cents per barrel. For direct production-i.e., pumping, cleaning, and pulling-10 cents per barrel may be safely assumed. For maintenance of surface-equipment and rigs, 4 cents is a conservative estimate. For exhaustion of oil-land, and redemption of capital, from 6 to 10 cents must be reckoned; and for drilling to maintain production, 12 cents is not excessive. These figures make a minimum of 32 cents and a maximum of 36 cents."

While Mr. Requa has arrived at his estimated cost by a different method of accounting, the average is practically the same, and it would be most instructive to have the opinion of other engineers on this subject. To draw attention to the proper application of depreciation to oil properties, and to its importance as an element in the cost of producing oil, is the purpose of this paper, and it is hoped that a full discussion will be made by those members of the Institute whose experience in the various oil fields of the world will be of great value, not only to engineers, but also to all those interested in the development of oil properties.

To sum up, my conclusions are:

That there should be set aside each year, out of earnings, a depreciation reserve, sufficient in amount to keep the property at a constant value, by providing a fund to take care of extraordinary wear and tear, inadequacy, obsolescence, and exhaustion.

That ordinary wear and tear should be charged directly into operating.

That depreciation reserve, being both a debit and a credit account, should be charged with extraordinary repairs and with replacements as made.

That depreciation reserve should not be applicable to the payment of dividends, but only for the repayment of principal.

That depreciation reserve may be invested in the property itself or in outside securities.

That the principles used in setting aside depreciation reserve should be those outlined by the Internal Revenue Bureau, quoted in the beginning of this paper. 
That in the application of these principles it is necessary to determine the lifetime of each item making up the property, but that, in view of the many uncertain factors pertaining to oil properties, it is sufficiently accurate to divide depreciable property into three classes-oil lands, field equipment, and wells-and determine the average lifetime of each class.

That these average lifetimes, with due consideration of remaining value upon exhaustion of oil, will determine the annual percentage to charge on these three items standing in capital account, the proceeds of which should be credited to depreciation reserve.

That these percentages, being based upon estimates, are subject to change, and should be verified at proper intervals by making actual valuations in order to determine whether the amount in depreciation reserve plus present value equals original value, as it should-neglecting other elements of valuation, and using cost and value as equivalent terms.

That in establishing lifetimes each property must be studied by itself, and different annual percentages must necessarily be adopted for different properties on account of the great variation in conditions.

That it would, however, be advantageous to establish for each oil field average percentages which could be used until such time as the characteristics of the different properties in the field are known.

That for California such average annual percentages should be 4 per cent. on cost of oil lands, 7 per cent. on cost of field equipment and 10 per cent. on cost of individual wells and appurtenances, but that these percentages should be changed in accordance with the development of the characteristics of the property under consideration.

That in the oil fields of California depreciation cost may equal or even exceed direct cost of producing oil per barrel.

These conclusions are not intended to be dogmatic, but rather for the purpose of stimulating discussion, for only by combining the experience and judgment of many engineers can depreciation be correctly applied to oil properties.

\section{Discussion}

C. E. Grunsky, Jr., San Francisco, Cal. (communication to the Secretary*).- The difference of opinion of engineers on the subject of depreciation is justified, to some extent, by the many viewpoints from which such a subject can be considered when applied to properties of widely differing physical characteristics.

Mr. Henry takes up the subject of depreciation as applied alone to oil properties, and in doing so makes a clear distinction between amortization and the repair or renewal requirement.

After carefully reading the paper the purpose of its author in suggesting a "depreciation" reserve or fund to keep the property at a constant

* Received Feb. 1, 1915. 
value does not seem clear. As shown by Mr. Henry, the depreciation element as compared with the operating expense per gallon of oil is very large because of the comparatively short life of the oil properties, and it is also evident that such a "depreciation" fund would in a short time contain a very large amount of money.

It seems desirable and permissible in income-tax matters to take into account the depreciation of property and to separate from the income such money as is necessary to amortize the invested capital to an extent warranted by the depreciation. However, it does not seem either necessary or desirable to create a large fund which will in time approximate the entire invested capital and which may be invested by the directors, as Mr. Henry suggests, "in the property itself or in outside securities."

This method seems cumbersome and liable to offer in the reinvestment of such a fund temptations to a directorate that might show more devotion to its own interests than that of the stockholders.

A reserve fund is very frequently desirable in mining and oil operations, but to keep up a fund of this magnitude or to reinvest it in outside securities does not seem desirable from a stockholders' standpoint. The money withdrawn from the receipts to be placed in the depreciation fund (not including replacements and the drilling of new wells necessary to keep up the productiveness) should be returned to the stockholders of the company, not as dividends, but as an amortization of the invested capital.

Past practice has been to return the invested capital as dividends, no differentiation being made between profits and returned capital, and no provision being made for any fund called a "depreciation" fund, or what you like, for the purpose of amortizing the capital. During the life of a property (annually if possible) all of this depreciation fund should be returned to the stockholders, excepting such portion as it is desirable to retain intact to insure the continuity of operations, and in such event outside investment from this fund by the directors should be prohibited.

In Form No. 1031 (revised), Return of Net Annual Income-Corporations, issued by the Internal Revenue Bureau, under the heading "5 (B) Depreciation and Depletion," the following limitation is placed on the amount to be deducted from income because of the exhaustion or the depletion of natural deposits: "In computing depletion in the case of natural deposits the rate should not exceed 5 per cent. of the gross value at the mine of the ouput for the year."

This requirement determines that the total amount deducted from the gross income during the life of the property, which is to be laid aside or returned to the investor as capital, shall not be more than $1 / 20$ of the gross value of the total production from the mine or oil property. If, under this ruling, the owners or investors pay a large sum of money for the property or erect an expensive plant because they can recover the prouct at a low cost per ton or per barrel and the investment exceeds this 
$1 / 20$ of the gross value of the total production, a portion only of their capital will be returned as dividends with the income tax subtracted from it.

The proper way to estimate this "depletion" is, as pointed out by Mr. Henry, to use as a basis for the estimated life the average life of the oil properties in the vicinity of any property. Then the annual depletion will be the annual installment which is necessary to return to the owner his legitimate or proper investment during that period of years.

When it is observed that the actual life of an oil property will be prolonged beyond that originally expected, the estimated life can be increased, and when it is seen that the output is decreasing rapidly, the reverse is possible. Under no circumstances, of course, should the owner be allowed to credit, because of the depletion of his property, more money to the depreciation fund than has been legitimately invested by him.

The fact that the remaining life of the properties may be extended . from time to time is discussed at some length by C. E. Grunsky in a paper published in the Transactions of the American Society of Civil Engineers. ${ }^{2}$ Those who care to go more deeply into this phase of the question may refer to this paper.

I. N. KNAPP, Ardmore, Pa. (communication to the Secretary*).-As a general accounting proposition on depreciation, Mr. Henry's paper is undoubtedly correct. In discussing his paper I can only give my personal experience and opinion from the standpoint of an oil and gas operator.

The depreciation on buildings, machinery, tanks, and pipe lines may be readily agreed upon, as they are on the surface and are easily examined as to their condition from time to time, and a civil engineer used to such public utilities would be entirely competent to pass on that part of the problem.

A government ruling as to depreciation or losses is too often a "heads I win, tails you lose" proposition which may have to be referred to the courts to tell what is meant. Such rulings may be applicable to the collection of taxes, but do not really tend to show whether any particular property or business is paying or not, or what may be the real depreciation.

To be properly qualified to estimate on the depreciation of oil and gas producing wells, which necessarily reach many feet below the surface,

* Received Mar. 2, 1915.

2 Depreciation as an Element for Consideration in the Appraisal of Public Service Properties, Transactions of the American Society of Civil Engineers, vol. xl, No. 9 (Nov., 1914). 
requires knowledge that can be acquired only by actual experience in drilling and operating.

The general public is very much misinformed as to the actual costs and depreciations of oil and gas properties. The fakir, the boomer of fraudulent oil and gas promotions, the space writer for the magazines, all have spread abroad a sort of idea that all that was necessary to get a big-paying property was to hire a driller to put a few pipes in the ground most anywhere and tap vast stores of -oil and gas provided by nature and get a perennial yield of oil and gas at a slight cost and no depreciation.

These ideas are reflected in legislation and decisions of the courts.

To assist the oil and gas producer to meet unwise legislation and imposition of unreasonable taxation and bureaucratic interferences, the producer must inform himself as to what the itemized costs of producing are and what the depreciation is on his properties.

Some years ago I operated in a small oil pool and kept my accounts according to a classification outlined by an accomplished accountant.

A record of all bills paid and the items received was sent in for monthly audit and a trial balance returned, thus giving a monthly check on the business.

Once a year a complete inventory was made, using the same measure of value for each producing well, and the depreciation for the year worked out. The routine work was done by clerks, but the trial balances and inventory sheets were checked and signed by the accountant.

We found the depreciation in yield on about 60 oil wells regularly operated was 3 per cent. per month, or about 28 per cent. per year. The total cost (including all proper charges and depreciation) of putting the oil into the field tanks was 53c. per barrel for a period of years.

The yield from gas wells was so erratic and measurements so uncertain that $I$ could never get a satisfactory line on the cost of production or depreciation. I regret that the books of this operation are no longer in existence, as they gave costs and depreciation in detail.

The wells were pulled out when from five to seven years old because oil fell to 27c. per barrel; it had been as high as $\$ 1.38$.

The operation had already paid out and made considerable profit, but our books showed that there was no margin at $27 \mathrm{c}$. for continued operation.

Possibly it would have paid to have kept the property for a rise in the price of oil. The reason for not doing so was the probable excessive depreciation of the property and wells when not regularly operated, the heavy taxation put on oil and gas properties; also the majority of the land owners insisted on continuous operation. 